\title{
Pentingnya Internet Sebagai Sarana Pendukung Kegiatan Belajar Pada Masa Pandemi Covid-19
}

\author{
Yudhistira' ${ }^{1}$, Hermanto $^{2}$, Nuraeni Herlinawati ${ }^{3}$, Muhammad Iqbal $^{4}$ \\ 1,2,3,4Universitas Bina Sarana Informatika \\ e-mail: 1'yudhistira.yht@bsi.ac.id, 2hermanto.hmt@bsi.ac.id, ${ }^{3}$ nuraeni.nhw@bsi.ac.id, \\ 4iqbal.mdq@bsi.ac.id
}

\begin{abstract}
Abstrak
Pengembangan IPTEK (Ilmu Pengetahuan dan Teknologi) memberikan peran dalam meningkatkan kesejahteraan dan perekonomian masyarakat. Berbagai bidang yang sudah dapat dirasakan dengan kehadirannya teknologi salah satunya adalah bidang pendidikan (Saryoko et al., 2020). Pentingnya peran serta dunia pendidikan tinggi dalam mendorong pembangunan tidak dapat dipungkiri lagi. Hal ini tercermin dalam pasal 20 UU No. 20 Tahun 2003 tentang Sistem Pendidikan Nasional (UU Diknas) yang menyatakan bahwa salah satu dharma Perguruan Tinggi, selain pendidikan dan penelitian, adalah kegiatan pengabdian masyarakat. Tri Dharma Perguruan Tinggi itu sendiri merupakan tiga pilar utama penyelenggaraan institusi perguruan tinggi. Untuk menunaikan salah satu Tri Dharma tersebut, dengan ini Universitas Bina Sarana Informatika melaksanakan Pengabdian Masyarakat. Saat ini Indonesia masih dalam situasi pandemi. Salah satu yang terdampak dalam pandemi saat ini adalah Warga RT. 010/03 Mampang Prapatan yang berada di Rukun Tetangga RT. 010/003 Jl. Mampang Prapatan VII Tegal Parang, Kota Jakarta Selatan. Banyak dari mereka yang masih kesulitan dalam menggunakan aplikasi pembelajaran daring. Oleh karena itu kami sebagai dosen dan mahasiswa Universitas Bina Sarana Informatika, Fakultas Teknik dan Informatika, program studi Teknologi Komputer, ingin memberikan pengetahuan kepada mereka tentang bagaimana menerapkan pembelajaran daring secara tepat dan efektif. Target yang akan kami capai terkait dengan pelaksanaan pengebdian masyarakat ini adalah untuk dapat membantu masyarakat warga RT 010/003 Mampang Prapatan untuk dapat lebih memahami penggunaan aplikasi secara daring. Selain itu juga output dari hasil pengabdian ini akan kami jadikan artikel untuk di terbitkan pada jurnal pengabdian masyarakat serta berita pada media online.
\end{abstract}

Kata Kunci: Teknologi, Pandemi, Online

\begin{abstract}
The development of Science and Technology (Science and Technology) plays a role in improving the welfare and economy of the community. Various fields that can already be felt by its presence, one of which is the field of education (Saryoko et al., 2020). Its important role and the world of higher education in encouraging development cannot be denied. This is in article 20 of Law no. 20 of 2003 concerning the National Education System (UU Diknas) which states that one of the dharmas of Higher Education, apart from education and research, is community service activity. Tri Dharma Perguruan Tinggi itself is the three main pillars in organizing
\end{abstract}


higher education. To fulfill one of the Tri Dharma, hereby Bina Sarana Informatics University carries out Community Service. Currently, Indonesia is still in a pandemic situation. One of the people affected by the current pandemic are RT residents. 010/03 Mampang Prapatan which is in the Neighborhood RT. 010/003 Jl. Mampang Prapatan VII Tegal Parang, South Jakarta City. Many of them still have difficulty using bold learning applications. Therefore, we as lecturers and students of Bina Sarana Informatics University, Faculty of Engineering and Informatics, Computer Technology study program, want to provide knowledge to them about how to apply bold learning appropriately and effectively. The target we will achieve in relation to the implementation of this community bombing is to be able to help the community members of RT 010/003 Mampang Prapatan to better understand the use of the application bravely. In addition, we will also turn the output of this service into articles to be published in community service journals as well as news in online media.

Keywords: Technology, Pandemic, Online

\section{Pendahuluan}

Pengembangan IPTEK (Ilmu Pengetahuan dan Teknologi) memberikan peran dalam meningkatkan kesejahteraan dan perekonomian masyarakat. Banyak sekali teknologi yang sudah diciptakan atau disediakan untuk mempermudah masyarakat dalam beraktifitas sehari-hari. Salah satu bentuk teknologi yang popular saat ini adalah internet. Menurut Adri dalam (Setiyani, 2010), Perkembangan internet telah mengubah paradigma dalam mendapatkan berbagai macam informasi. Melalui internet kita dapat memperoleh informasi yang kita butuhkan dimanapun dan kapanpun. Berbagai bidang yang sudah dapat dirasakan dengan kehadirannya teknologi salah satunya adalah bidang pendidikan.(Saryoko et al., 2020). Menurut Era dalam (Saryoko, Susafa'ati, et al., 2021) peningkatan penguasaan ilmu dan teknologi tidak hanya dilakukan pada pendidikan formal, namun juga dapat dilakukan melalui pendidikan nonformal. Saat ini penggunaan Teknologi Informasi di masyarakat sudah menjadi hal sehari-hari yang dugunakan, tetapi pengetahuan mengenai ICT belum semua masyarakat mengetahuinya secara maksimal (Saryoko, Ramanda, et al., 2021).

Pentingnya peran serta dunia pendidikan tinggi dalam mendorong pembangunan tidak dapat dipungkiri lagi. Hal ini tercermin dalam pasal 20 UU No. 20 Tahun 2003 tentang Sistem Pendidikan Nasional (UU Diknas) yang menyatakan bahwa salah satu dharma Perguruan Tinggi, selain pendidikan dan penelitian, adalah kegiatan pengabdian masyarakat. Selain itu, pasal 24 UU Diknas menyatakan adanya otonomi Perguruan Tinggi untuk mengelola sendiri lembaganya sebagai pusat penyelenggaraan pendidikan tinggi, penelitian ilmiah, dan pengabdian kepada masyarakat. Tri Dharma Perguruan Tinggi itu sendiri merupakan tiga pilar utama penyelenggaraan institusi perguruan tinggi. Untuk menunaikan salah satu Tri Dharma tersebut, dengan ini Universitas Bina Sarana Informatika melaksanakan Pengabdian Masyarakat. Hal ini dilaksanakan berkaitan dengan kepedulian setiap 
lembaga atau institusi yang bergerak di bidang pendidikan, khususnya Pendidikan Tinggi dengan mengikuti perkembangan dan kemajuan teknologi.

Saat ini dunia termasuk Indonesia sedang dalam masa krisis pandemi covid-19. Menurut Kementrian Kesehatan dalam (Hermanto \& Noviriandini, 2021) Corona virus 19 (COVID-19) merupakan virus yang menyerang pernafasan manusia, dan pertama kali menyebar luas di Wuhan, Provinsi Hubei, Cina. Dampak dari pandemi ini salah satunya adalah kegiatan belajar mengajar yang dilakukan secara daring. Banyak sekali siswa-siswi dari mulai SD sampai SMA yang harus menyesuaikan diri untuk dapat menggunakan aplikasi yang menyediakan fasilitas pembelajaran secara daring.

Salah satu yang terdampak dalam pandemi saat ini adalah Warga RT. 010/03 Mampang Prapatan yang berada di Rukun Tetangga RT. 010/003 Jl. Mampang Prapatan VII Tegal Parang, Kota Jakarta Selatan. Banyak dari mereka yang masih kesulitan dalam menggunakan aplikasi pembelajaran daring. Oleh karena itu kami sebagai dosen dan mahasiswa Universitas Bina Sarana Informatika, Fakultas Teknik dan Informatika, program studi Teknologi Komputer, ingin memberikan pengetahuan kepada mereka tentang bagaimana menerapkan pembelajaran daring secara tepat dan efektif.

\section{Metode}

Kami melaksanakan pengabdian masyarakat ini dengan metode penyampaian materi dari tutor menggunakan zoom meeting dimana para peserta berkumpul di aula RT 010/003 dengan sebagian panitia datang untuk menyiapkan perlengkapan dan mengkondisikan peserta. Berikut adalah tahapan dari pelaksanaan pengabdian masyarakat yang kami lakukan:

1. Tim melakukan koordinasi dengan pihak mitra yaitu ketua RT 010/003 Mampang Prapatan VII

2. Tim mengecek ketersediaan tempat dan perlengkapan utk pelaksanaan pengabdian masyarakat di lokasi.

3. Tim mengarahkan peserta pada saat pelaksanaan pengabdian masyarakat untuk berkumpul di aula lokasi.

4. Tutor menyampaikan pelatihan secara online melalui aplikasi zoom, sedangkan sebagian panitia dan semua peserta mendengarkan dari aula di lokasi.

5. Tim melakukan evaluasi terhadap pelaksanaan pengabdian masyarakat.

\section{Hasil dan Pembahasan}

Kegiatan pengabdian masyarakat ini dibagi menjadi 2 pertemuan. Para peserta berkumpul di aula RT 010/003 dengan didampingi oleh sebagian panitia. Sedangkan tutor menyampaikan materi menggunakan aplikasi zoom meeting. Jumlah peserta yang mengikuti kegiatan pengabdian masyarakat ini sebanyak 10 orang peserta. 
Pada pertemuan pertama yang dilaksanakan pada tanggal 13 Maret 2021 membahas mengenai pemanfaatan internet sebagai media pembelajaran. Tutor menyampaikan bagimana pemanfaatan internet khususnya pencarian google dalam membuat sebuah artikel.

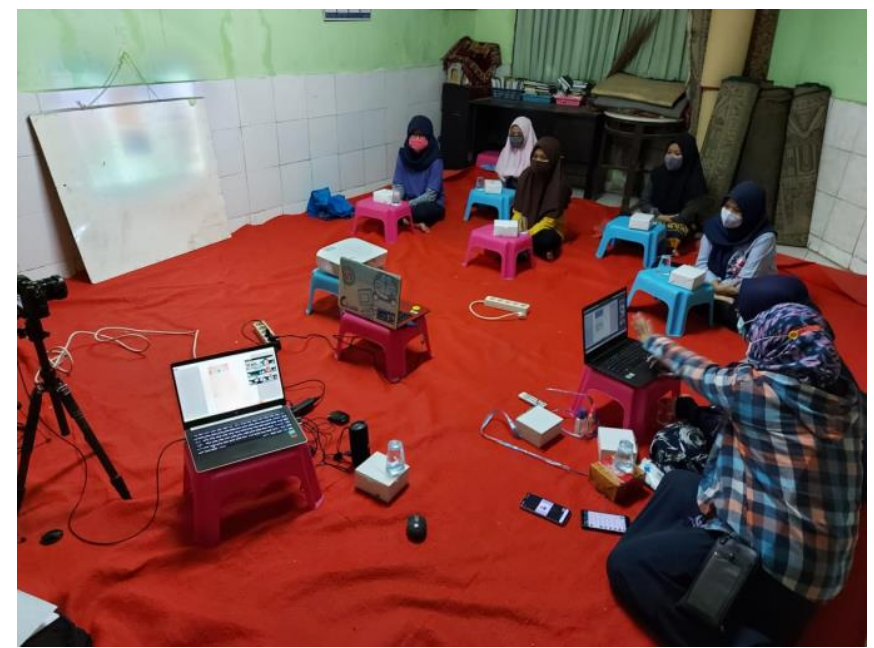

Gambar 1. Peserta berkumpul di Aula

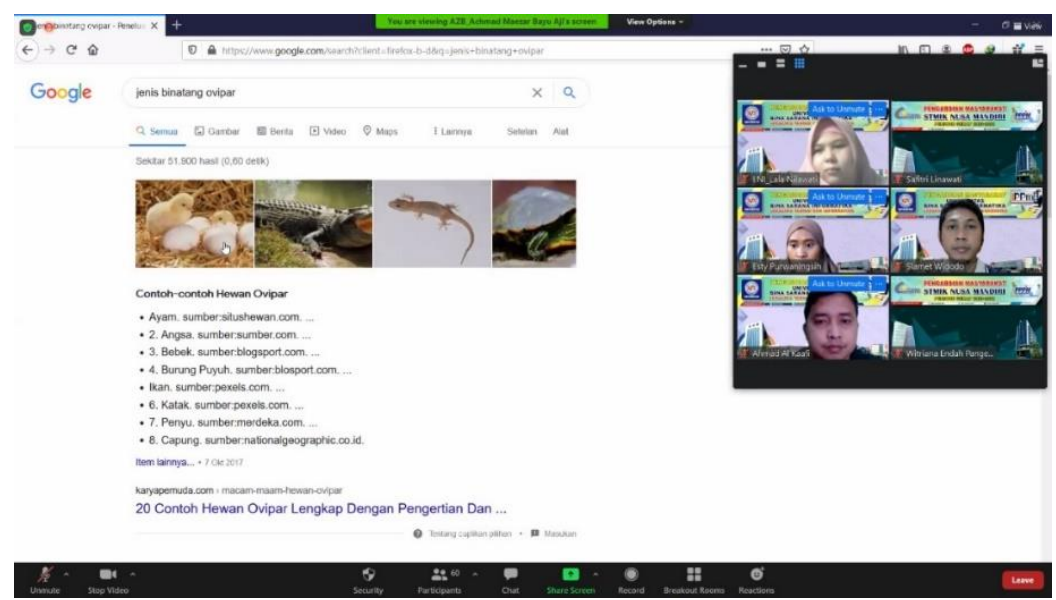

Gambar 2. Tutor menyampaikan materi 1

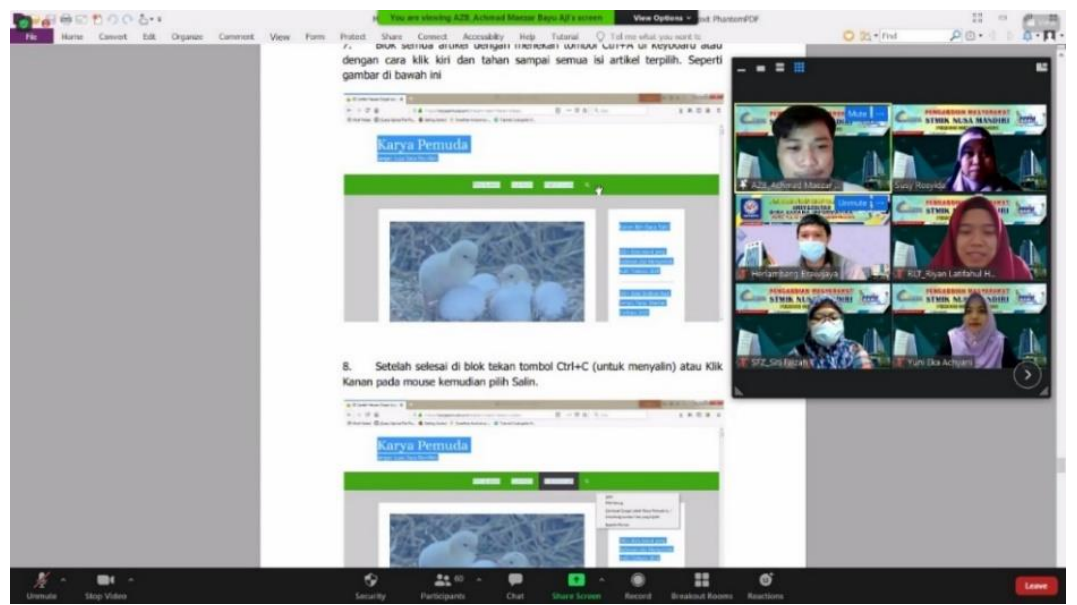

Gambar 3. Tutor menyampaikan materi 1 
Pada pertemuan kedua yang dilaksanakan pada tanggal 14 Maret 2021, tutor menyampaikan materi mengenai pemanfaatan youtube. Tutor menjelaskan bagaimana youtube bisa dimanfaatkan sebagai media pembelajaran dan dapat dijadikan juga sebagai media yang dapat menghasilkan keuntungan.

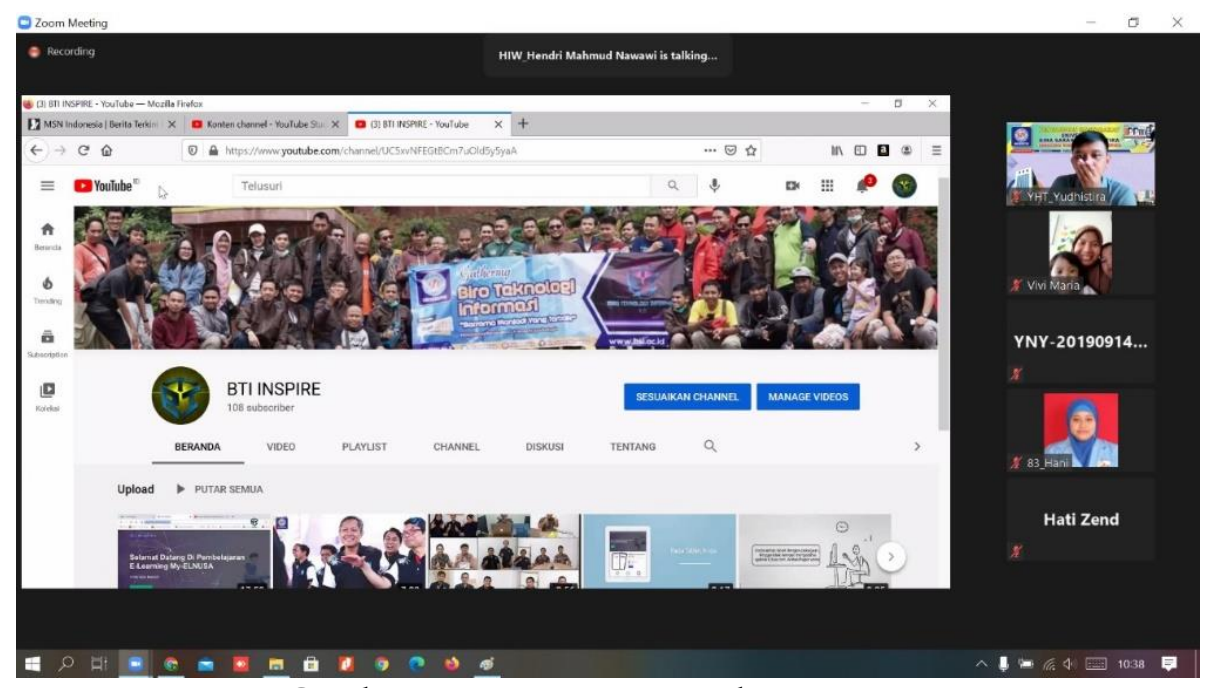

Gambar 4. Tutor Menyampaikan Materi 2

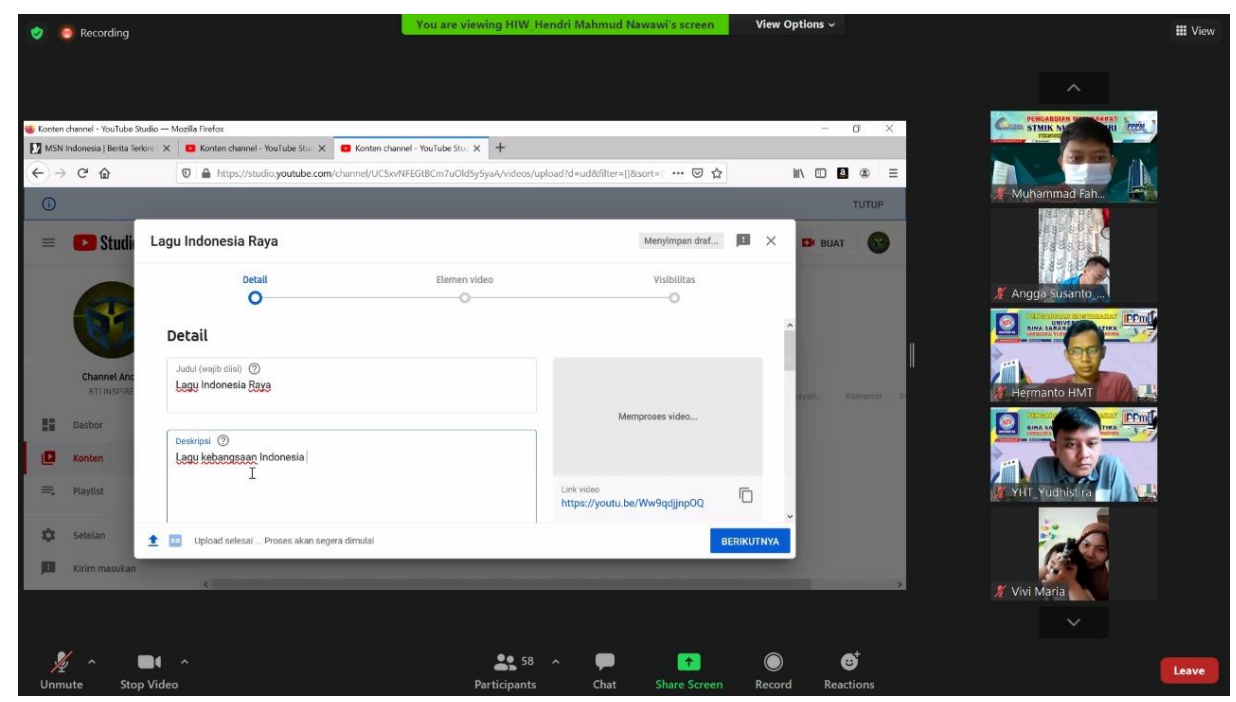

Gambar 5. Tutor menyampaikan materi 2

Adapun hasil yang didapatkan dari pengabdian masyarakat ini adalah:

1. Para peserta memahami pemanfaatan internet sebagai media pembelajaran yang efektif di tengah pandemic.

2. Para peserta memahami cara penggunaan youtube dalam mendokumentasikan kegiatan-kegiatannya ataupun memanfaatkannya sebagai penghasilan tambahan.

Berikut beberapa evaluasi dari pelaksanaan pengabdian masyarakat ini:

1. Jaringan koneksi internet masih belum maksimal sehingga beberapa kali penjelasan dari tutor melalui aplikasi zoom meeting terputus. 
2. Perangkat seperti laptop masih terbatas sehingga jumlah peserta tidak bisa banyak.

\section{Simpulan dan Rekomendasi}

Melalui pengabdian kepada masyarakat yang telah dilaksanakan dapat disimpulkan bahwa pengetahuan dalam pemanfaatan internet melalui google dan youtube sangat bermanfaat bagi para peserta. Secara keseluruhan kegiatan pengabdian kepada masyarakat yang dilakukan berjalan dengan baik. Peserta antusias mengikuti kegiatan dan berharap ada kegiatan lanjutan.

\section{Daftar Pustaka}

Hermanto, \& Noviriandini, A. (2021). Analisa Sentimen Terhadap Belajar Online Pada Masa Covid-19 Menggunakan Algoritma Support Vector. 5(1), 129-136.

Saryoko, A., Ramanda, K., Rosyda, S., \& Sari, R. (2021). Pelatihan Dasar Animasi Menggunakan Macromedia Flash Pro 8 . 0 Untuk. 1(April), 35-38.

Saryoko, A., Sari, R., Rianto, V., \& Rosyida, S. (2020). Pemanfaatan IPTEK Dalam Kegiatan Belajar Mengajar Untuk Masyarakat Pela Mampang Di Masa Pandemi. ABDIMAS: Jurnal Pengabdian Masyarakat, 3(2), 304-310. https://doi.org/10.35568/abdimas.v3i2.920

Saryoko, A., Susafa'ati, Ardiansyah, \& Kholis, N. (2021). Jurnal Abdimas Ekonomi dan Bisnis Pendampingan UMKM Ipunk Snack and Coocies Dalam Mempertahankan dan Meningkatkan Usaha Perekonomian Menggunakan Teknologi di Masa Pandemi Covid19 Jurnal Abdimas Ekonomi dan Bisnis. 1(1), 12-18.

Setiyani, R. (2010). Pemanfaatan Internet Sebagai Sumber Belajar. Dinamika Pendidikan Unnes, 5(2), 117-133. https:/ / doi.org/10.15294/dp.v5i2.4921 